\title{
AKSELERASI PENINGKATAN KESEHATAN DI INDONESIA : EFEKTIVITAS KEMOTERAPI KANKER PROSTAT DENGAN ANALISIS TINGKAT TUMOR MARKER PASIEN MENGGUNAKAN PERSAMAAN DIFFERENSIAL
}

\author{
Bagaskoro Cahyo Laksono', Ika Yuni Wulansari² \\ ${ }^{1}$ Politeknik Statistika STIS \\ 211810211@stis.ac.id
}

\begin{abstract}
ABSTRAK
Interaksi biologis sel-sel dalam tubuh serta pertumbuhan dan pembelahan sel kanker dapat diaplikasikan ke dalam model matematika. Pertumbuhan kanker dapat dimodelkan dalam bentuk persamaan ekponensial. Untuk membuat model pertumbuhan kanker secara eksponensial dapat didekati dengan pertumbuhan tumor marker. Tingkat Tumor Marker di atas batas normal yang dihasilkan sel tubuh dapat mereprentasikan banyaknya sel kanker yang tumbuh. Salah satu tumor marker dalam tubuh adalah PSA, prostate-specific antigen, yang mengindikasikan jumlah sel kanker dalam kelenjar prostat. Sel dalam tubuh tumbuh dengan melakukan pembelahan. Pertumbuhan yang berlipat ini dapat didekati dengan fungsi eksponensial. Sel kanker merupakan sel tubuh yang pembelahannya tak terkendali. Secara alami tubuh menekan pertumbuhan kanker dengan system imun. Namun terkadang imun tidak cukup kuat untuk menahannya sehingga diperlukan pengobatan. Kondisi imun tubuh berpengaruh pada laju pertumbuhan kanker (dilambangkan $\boldsymbol{g}$ ) dan respon tubuh terhadap kemoterapi berpengaruh pada laju penurunan kanker (dilambangkan $\boldsymbol{d}$ ). Persamaan pertumbuhan sel kanker yang dalam hal ini direpresentasikan oleh kadar PSA terhadap waktu dapat dimodelkan dengan persamaan $\boldsymbol{P S A}(\boldsymbol{t})=\mathbf{4} \boldsymbol{e}^{(\boldsymbol{g}-\boldsymbol{d}(\boldsymbol{t})) t}$. Semakin besar nilai $d$ terhadap nilai $g$ maka penurunan PSA akan semakin cepat, artinya waktu penyembuhan semakin cepat. Dengan empat titik data PSA pasien yang diambil pada waktu yang berbeda, dapat diprediksi umur kanker sejak pertama kali muncul dan waktu tubuh akan sembuh dari kanker. Karena efek kemoterapi terhadap tubuh memiliki periode tertentu yang membuat pengobatan ini harus dijalani beberapa kali, tujuan dari penelitian ini yaitu menghasilkan model efektivitas kemoterapi. Harapannya dengan adanya model ini lama penyembuhan dan biaya yang dikeluarkan pasien dapat ditekan dan semakin efektif. Hal ini selaras dengan tujuan Sustainable Development Goals nomor tiga yaitu menjamin kehidupan yang sehat dan meningkatkan kesejahteraan penduduk di segala usia yang strategi utamanya adalah akselerasi pemenuhan dan peningkatan akses pelayanan kesehatan dan meningkatkan pengendalian penyakit.
\end{abstract}

Kata kunci: model, kanker, tumor marker, PSA

Biological interactions of cells in human body included the growth and division of cancer cells can be applied in mathematical model. Cancer growth can be modeled in the form of exponential equation. To create a model of cancer exponential growth can be approximated by tumor marker level. Tumor marker level represents the number of cancer cells in human body. One of tumor marker in human body is PSA, Prostate-Specific Antigen, which indicates the number of cancer cells in prostate gland. Because of cancer cells grow uncontrollably, the growth of cancer cells can be approximated by an exponential function. Actually human body has immune system to suppress the growth of cancer. But sometimes the immune not strong enough to handle cancer, so needed some treatment to kill cancer cells. The immune's conditions affect the rate of cancer growth (denoted $\boldsymbol{g}$ ) and the body's response to drugs from treatment affect the rate of cancer decay (denoted $\boldsymbol{d}$ ) in this case is chemotherapy. Equation growth of cancer cells, will be represented by the PSA levels which can be modeled by the equation PSA $(\boldsymbol{t})=\mathbf{4} \boldsymbol{e}^{(\boldsymbol{g}-\boldsymbol{d}(\boldsymbol{t})) \boldsymbol{t}}$. The greater value $\boldsymbol{d}$ to the value $\boldsymbol{g}$, makes the decrease of PSA even faster. It means the healing time will be faster too. With three data points PSA from patient which taken at different times, the cancer first appeared and how long cured process will be predictable. Chemotherapy effect on the body have a certain period that makes this treatment should be undertaken several times. The purpose of this research is to create model of the effectiveness of chemotherapy. The impact is the healing process and patient costs could be reduced. This is in line with the goal of SDG's number three, which is to guarantee healthy lives and improve the welfare of people of all ages, whose main strategy is to accelerate the fulfillment and increase access to health services and improve disease control.

Keywords: model, cancer, tumor marker, PSA 


\section{Latar Belakang}

Berdasarkan statistik dari Organisasi Kesehatan Dunia (WHO), penyakit kanker adalah penyebab kematian nomor dua di dunia setelah penyakit jantung. Berdasarkan data Globocan menyebutkan bahwa di tahun 2018 terdapat 18,1 juta kasus baru kanker dengan angka kematian sebesar 9,6 juta kejadian di dunia. Di Indonesia, menurut data statistik Departemen Kesehatan, dilihat dari perbandingan seluruh penduduk di Indonesia 1 dari 700 orang positif menderita kanker. Angka kejadian kanker di Indonesia 136.2 per 100.000 penduduk berada diurutan 8 di Asia Tenggara. Berdasarkan data dari Riskesdas, prevalensi tumor/kanker di Indonesia menunjukkan adanya peningkatan dari 1,4 per 1000 penduduk di tahun 2013 menjadi 1,79 per 1000 penduduk di tahun 2018.

Dis samping itu, salah satu pengobatan kanker yang paling efektif adalah kemoterapi. Kemoterapi memiliki dampak yang cukup signifikan terhadap penurunan sel kanker karena kemoterapi berfungsi untuk membunuh dan menghambat pertumbuhan sel kanker itu sendiri. Namun disisi lain kemoterapi merupakan pengobatan yang membutuhkan biaya yang tidak sedikit juga. Kalangan menengah kebawah cenderung enggan untuk melakukan kemoterapi karena dinilai mahal dan tidak sedikit dari mereka yang lebih memilih untuk membiarkan penyakitnya dan hal itu menjadikan kemungkinan meninggal lebih besar karena kanker merupakan penyakit yang tidak mengenal pandang bulu dalam menyerang para korbannya baik orang kaya maupun miskin.

Penelitian ini juga berkaitan dengan perumusan suatu metode baru yaitu model efektivitas kemoterapi yang berguna untuk pemprediksian waktu pengobatan secara tepat dan presisi. Selama ini cenderung belum ada metode yang pasti yang digunakan dokter untuk mendiagnosis tingkat keseriusan penyakit kanker yang diderita pasien. Pemeriksaan dilakukan cenderung bersifat kualitatif yaitu memeriksa kondisi badan pasien yang sakit, seberapa bengkak bagian tubuh yang terkena kanker, pemeriksaan kondisi darah dan lain-lain. Sampai sekarang belum diciptakan teknologi medis pendeteksi langsung kondisi sel kanker.

\section{Rumusan Masalah}

Berdasarkan latar belakang diatas, dapat di tentukan rumusan masalah dari penelitian sebagai berikut :

a. Bagaimana mekanisme pertumbuhan sel kanker yang terjadi dalam tubuh manusia?

b. Bagaimana cara memodelkan pertumbuhan sel kanker tersebut?

c. Bagaimana cara membuat model efektivitas kemoterapi untuk penyembuhan kanker?

\section{Tujuan}

a. Memodelkan pertumbuhan sel kanker

b. Menentukan umur kanker dengan tujuan untuk mendapatkan rekam medis pasien

c. Menentukan jadwal kemoterapi yang paling efektif dan perkiraan lama penyembuhan

\section{Manfaat}

Manfaat dari hasil penelitian ini adalah metode yang diciptakan penulis dapat diaplikasikan dalam teknologi medis dan kedokteran. Sehingga dampak dengan diketahuinya umur kanker pasien, dapat ditentukan juga rekam jejak sumber kanker yang dialami pasien sebelum terkena penyakit. Selain itu prediksi lama penyembuhan kanker dan model efektifitas kemoterapi yang diciptakan penulis diharapkan dapat digunakan oleh pihak medis untuk menyusun strategi pengobatan agar lebih efektif dan efisien. Harapan dengan adanya hasil dari penelitian ini dapat dimanfaatkan oleh dunia medis dan kedokteran untuk mentukan umur kanker dan prediksi lama penyembuhan pasien secara akurat. Kemudian lebih lanjut, pihak medis dapat menyusun strategi pengobatan agar efektif dan efisien, misalnya untuk penjadwalan pengobatan. Manfaat untuk para penderita kanker sendiri, dengan adanya penjadwalan pengobatan yang tepat waktu dan biaya yang dikeluarkan pasien dapat ditekan dan diefisiensikan. 


\section{METODE}

Tumor marker adalah zat yang diproduksi oleh sel tubuh dalam kadar yang sedikit. Suatu sel normal dalam tubuh dapat memproduksi suatu zat tertentu dan zat tersebut berbeda tiap sel normal. Masing-masing sel tubuh menghasilkan tumor marker yang berbeda-beda. Jika sel tumor marker melebihi batas normal maka dapat dindikasikan adanya sel kanker tertentu yang tumbuh. Banyaknya tumor marker sebanding dengan jumlah sel yang memproduksi. Jika sel tersebut adalah sel kanker maka laju peningkatan tumor marker sebanding dengan laju pertumbuhan sel kanker. Salah satu tumor marker adalah Prostate Spesific Antigen (PSA) yang dihasilkan oleh sel kelenjar prostat. Dalam keadaan normal, kadar PSA pada darah sebanyak $4 \mathrm{ng} / \mathrm{ml}$. Ketika seseorang terkena kanker prostat maka produksi PSA akan meningkat. Semakin parah penyakit kanker prostat seseorang, maka produksi PSA akan meningkat (diatas batas normal). Jadi produksi PSA diatas normal dapat memrepresentasikan tingkat keseriusan penyakit kanker yang dialami seseorang. Tingkat PSA digunakan untuk memonitori keefektifan pengobatan kanker prostat dan untuk mengecek kesembuhan setelah pengobatan berakhir. Seperti halnya menguji kadar sel darah, kadar PSA diukur dengan pengujian serum di laboratorium.

Kemoterapi merupakan salah satu terapi penyembuhan penyakit kanker. Kemoterapi merupakan metode pengobatan yang memiliki fungsi untuk menghambat pembelahan sel kanker dan membunuhnya sehingga perlahan sel kanker akan menghilang. Namun dilain sisi kemoterapi dapat menghambat juga pembelahan sel-sel lain yang sedang aktif membelah seperti sel rambut sehingga menimbulkan kerontokan rambut dan kebotakan. Selain itu kemoterapi dapat menimbulkan gangguan mual, muntah dan lain lain. Kadang-kadang kemoterapi dapat menyebabkan efek jangka panjang. Misalnya: Kerusakan organ, seperti kerusakan jantung, ginjal, hati, paru-paru atau otak, Infertilitas, hingga peningkatan risiko kanker lainnya. Maka dari itu selain membahayakan tubuh pasien itu sendiri dan memperbesar resiko kematian, kemoterapi juga memiliki biaya yang tidak sedikit. Biaya kemoterapi termurah yaitu Rp. 3 juta per sesi, tetapi ada juga yang diatas Rp. 10 juta per sesi bahkan puluhan juta rupiah per sesi tergantung stadium kanker. Maka dari itu diperlukan suatu model efektifitas kemoterapi dengan memperhatikan banyaknya kemoterapi dan lamanya waktu penyembuhan sehin]gga pasien dapat sembuh dengan waktu yang optimal dan terhindar dari resiko kematian dan biaya.

Di samping itu, pembentukan model dimulai dari mendefinisikan konsep masalah. Penyelesaian masalah dalam penelitian ini menggunakan persamaan diferensial. Pertumbuhan sel kanker dan efek kemoterapi yang direpresentasikan oleh kadar PSA terhadap waktu, dimodelkan dengan persamaan diferensial secara umum sebagai berikut : $\frac{\boldsymbol{d}}{d \boldsymbol{t}} \boldsymbol{P} \boldsymbol{S} \boldsymbol{A}(\boldsymbol{t})=(\boldsymbol{g}-\boldsymbol{d}(\boldsymbol{t})) \boldsymbol{P S} \boldsymbol{A}(\boldsymbol{t})$. Lebih lanjut akan dibahas dalam bab selanjutnya.

Dalam penelitian ini, data yang digunakan beberapa sampel penderita kanker prostat dari official statistic yang di keluarkan oleh National Center For Biotechnology Information di website (www.ncbi.nlm.nih.gov). Penulis menganalisis dan mengolah data dengan menggunakan software Matlab dan MAPLE untuk menghasilkan beberapa plot/grafik yang mereprentasikan model yang akan dibuat. Interaksi biologis sel-sel dalam tubuh serta pertumbuhan dan pembelahan sel kanker dapat diaplikasikan kedalam model matematika. Pembangunan suatu model matematika berawal dari suatu model yang sederhana. Berbagai kendala dibatasi dan asumsi-asumsi yang logis digunakan untuk membangun suatu model. Model matematika yang dibuat dalam karya tulis ini adalah model pertumbuhan sel kanker yang didekati dengan petumbuhan sel tumor marker. Sehingga diakhir penelitian nanti didapatkan prediksi secara eksak tentang kondisi kanker yang diderita pasien. Dalam penelitian ini, penulis menyusun langkah-langkah penelitian dalam flowchart seperti berikut: 


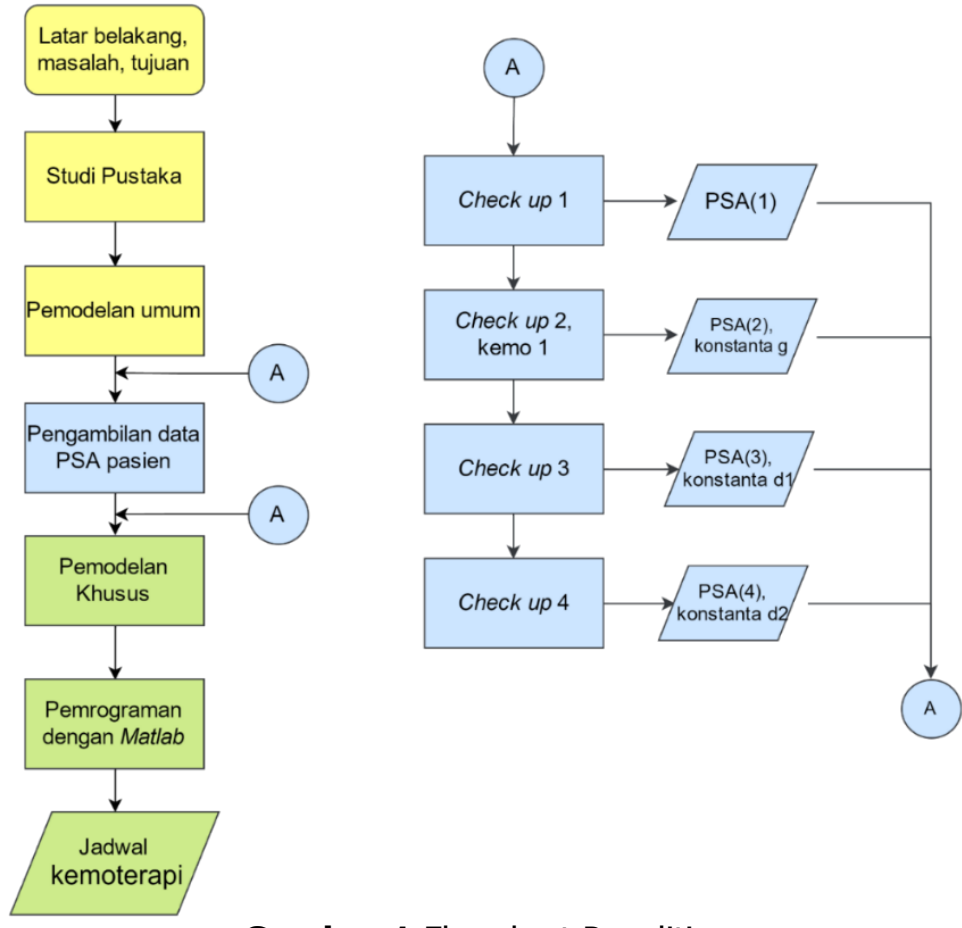

Gambar 1 Flowchart Penelitian

\section{HASIL DAN PEMBAHASAN}

\section{Model Pertumbuhan Sel Kanker Prostat dengan Analisis Tumor Marker}

Sejatinya semua sel pada tubuh membelah dengan intensitas pembelahan yang sama yaitu $2^{n}$ sel. Dari satu menjadi dua, dua menjadi 4 dst. Begitu juga sel kanker yang membelah tiap waktu membentuk deret geometri. Sehingga dapat dikatakan bertumbuh dengan eksponensial.

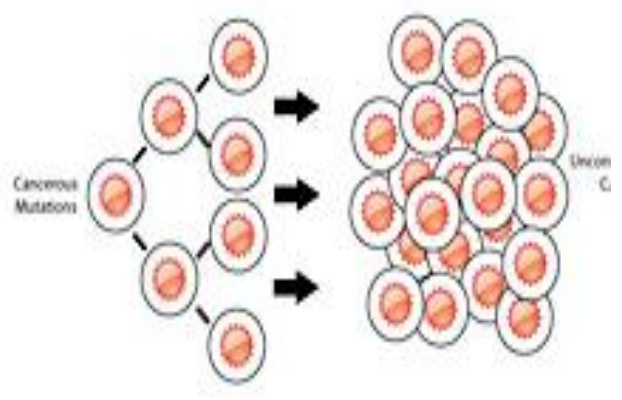

Gambar 2. Pembelahan Sel Kanker

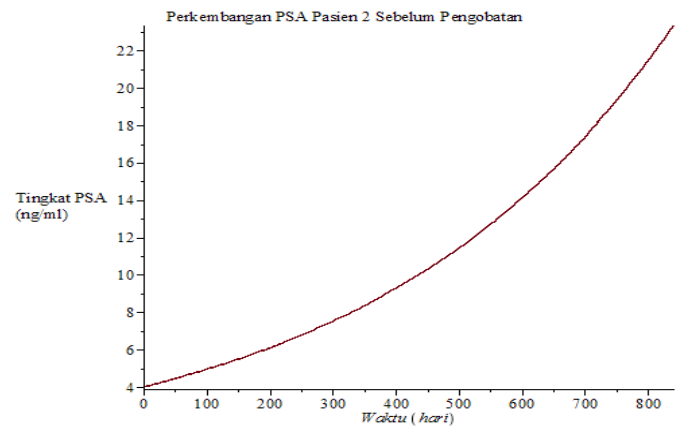

Gambar 3. Kurva Pertumbuhan Kanker

Dalam subbab ini akan dibahas mengenai pendekatan model pertumbuhan kanker prostat dengan menggunakan tumor marker Prostate Spesific Antigen (PSA). Seperti yang sudah dibahas sebelumnya, penulis akan menggunakan data tumor marker pasien untuk mereprentasikan pertumbuhan sel kanker. Penulis mengembangkan suatu persamaan menjadi suatu model berdasarkan pertumbuhan tingkat PSA secara eksponensial. Persamaan berikut adalah model persamaan differensial orde 1 dengan nilai awal $\operatorname{PSA}(0)=4 \mathrm{ng} / \mathrm{mm}$ yang merupakan nilai batas normal PSA dalam darah. Satuan waktu yang digunakan adalah hari.

$$
\frac{d}{d t} P S A(t)=g \cdot P S A(t) ; P S A(0)=4 n g / m m
$$

Keterangan: $\quad \operatorname{PSA}(\mathrm{t})=$ tingkat PSA pasien terhadap waktu $\left(\frac{n g}{m l}\right)$

$$
\begin{aligned}
& \mathrm{g}=\text { growth/ koefisien kenaikan PSA }\left(\frac{1}{\text { satuan waktu }}\right) \\
& \mathrm{d}=\text { decay/ koefisien penurunan tingkat PSA }\left(\frac{1}{\text { satuan waktu }}\right)
\end{aligned}
$$


Dengan melakukan analisis dan penurunan persamaan, didapatkan sebuah solusi koefisien pertumbuhan PSA $(\mathrm{g})$ dan umur kanker $\left(\mathrm{t}_{0}\right)$ sebagai berikut:

$$
g=\frac{1}{t_{1}} \ln \left|\frac{P S A 2}{P S A 1}\right| \quad t_{0}=\frac{1}{g} \ln \left|\frac{P S A 1}{4}\right|
$$

\section{Analisis Periode Kemoterapi}

Pada subbab ini akan dibahas mengenai efek dari kemoterapi kedalam tubuh pasien dengan tujuan untuk menentukan lama kinerja kemoterapi dalam tubuh. Melalui studi pustaka diketahui bahwa respon tubuh terhadap pertumbuhan kanker tiap orang berbeda-beda bergantung kepada kondisi tubuh pasien meliputi pengaruh sel imun, sel darah dan lain-lain. Begitupun efek kemoterapi pada tiap tubuh orang berbeda-beda juga. Kemoterapi adalah salah satu jenis pengobatan kanker yamg memiliki efek yang tidak kontinu, semakin lama semakin hilang. Dalam satu periode waktu tertentu, kemoterapi tidak akan memiliki efek kerja ke tubuh. Maka dari itu kemoterapi perlu dilakukan beberapa kali untuk mengupgrade efek kerja kemoterapi ke tubuh pasien. Efek kemoterapi berpengaruh kedalam koefisien $\mathrm{d}$ (decay). Nilai koefisien d dapat berubah terhadap waktu dan suatu saat akan menuju nol. Sehingga penulis dapat memodelkan perubahan $\mathrm{d}(\mathrm{t})$ dengan fungsi eksponensial turun terhadap waktu.

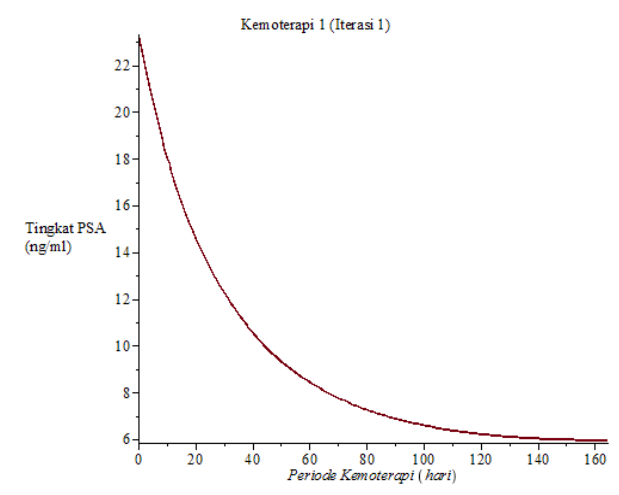

Gambar 4. Efek Komoterapi terhadap Waktu

Dengan analisis yang sudah ada, mendeklarasikan fungsi kemoterapi adalah $d(t)$ yang dapat dimodelkan seperti persamaan berikut:

$$
\frac{d}{d t} d(t)=-k \cdot d(t)
$$

Berdasarkan hasil studi pustaka yang telah dilakukan, pada dasarnya disaat kemoterapi dilakukan sel kanker tetap memiliki laju pertumbuhan tingkat PSA. Namun disisi lain dengan adanya kemoterapi terdapat juga laju penurunan tingkat PSA. Sehingga dari dua model yang telah dibangun diatas dapat digabungkan menjadi persamaan utama yaitu:

$$
\frac{d}{d t} P S A(t)=(g-d(t)) . P S A(t) ; P S A(0)=P S A 2
$$

Keterangan: $\quad$ PSA2 $=$ tingkat PSA pasien sesaat sebelum dilakukan kemoterapi

Disaat kemoterapi dilakukan, sel kanker memiliki laju kenaikan tingkat PSA yang konstan sedangkan laju penurunanan PSA dari efek kemoterapi lama-kelamaan akan habis. Sehingga hal itu memunculkan satu momen saat efek kemoterapi berkurang, maka PSA akan kembali naik. Hal ini yang menjadi sub-pembahasan dalam model yang akan penulis buat.

Berdasarkan analisis dari persamaan utama diatas, agar kemoterapi memiliki efek kerja di dalam tubuh pasien maka nilai ( $\mathrm{g}-\mathrm{d}$ ) haruslah negatif sehingga grafik akan eksponensial turun. Karena dengan itu plot grafik perkembangan kanker akan turun, dan kanker akan berangsur-angsur sembuh. Sehingga dengan analisis konsep dapat disimpulkan bahwa efek kemoterapi dinilai sudah tidak efektif yaitu ketika nilai $\mathrm{d}(\mathrm{t})<=\mathrm{g}$. Maka dari itu penulis akan menentukan nilai periode kemoterapi saat $\mathrm{d}(\mathrm{t})$ sama dengan g.

$$
d(t)=C \cdot \exp \left(-k t_{\text {kemoterapi }}\right)=g
$$


Periode kemoterapi dalam dunia medis merupakan inovasi baru yang belum pernah ditemukan sebelumnya. Peran periode kemoterapi sangat krusial dalam menentukan waktu yang tepat untuk melakukan pengobatan kemoterapi. Dengan analisis yang dilakukan diatas didapat persamaan periode kemoterapi seperti berikut :

$$
t_{\text {kemoterapi }}=\frac{t 2 \cdot \ln \left|\frac{g}{\mid \sqrt[t 2-t 3]{\frac{d 2^{t 2}}{d 1^{t 3}}}}\right|}{\ln \left|\frac{d \mathbf{1}}{t 2-t 3}\right| \frac{\sqrt{\frac{d 2^{t 2}}{d 1^{t 3}}}}{\mid}} \mid
$$

\section{Model Efektivitas Kemoterapi}

Model efektifitas kemoterapi sangat bermanfaat di dalam dunia medis karena dapat menguntungkan banyak pihak yaitu pasien maupun dari tim medis. Pihak pasien akan merasa lebih ringan dalam pembiayaan pengobatan karena dengan adanya efektifitas ini kemoterapi menjadi efektif dan waktu sembuh juga dapat dipercepat. Model efektifitas kemoterapi diperoleh dari analisis periode kemoterapi yaitu suatu titik disaat koefisien $\mathrm{d}=\mathrm{g}$. Definisi efektif yang penulis bangun adalah jumlah kemoterapi seminimal mungkin dalam jangka pengobatan sesingkat mungkin. Untuk membangun model yang cocok, penulis terlebih melakukan analisis grafik perbandingan sebagai berikut:

\section{Model 1 (selang kemoterapi terlalu lama):}

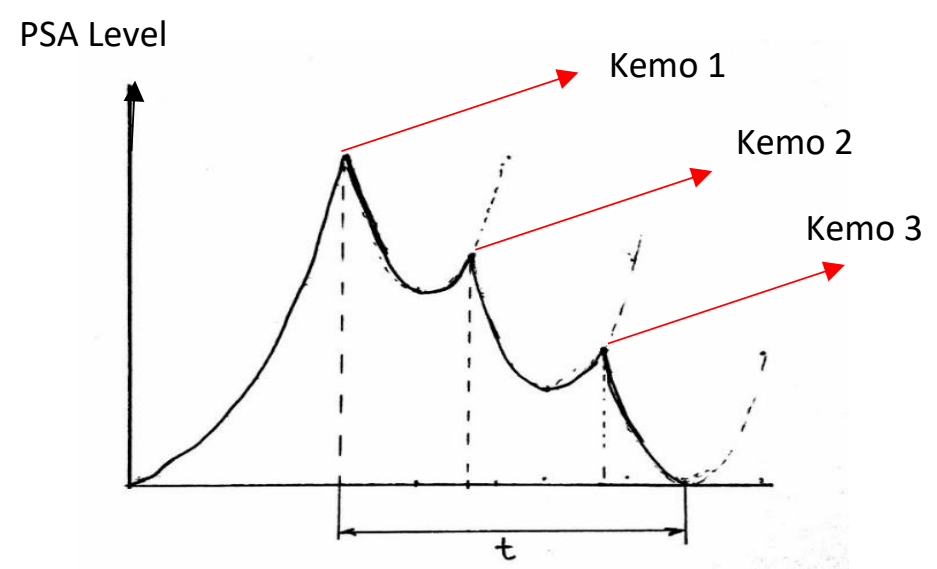

Gambar 5. Analisis Model 1

Model ini memperlihatkan bahwa selang antar kemoterapi terlampau lama, sehingga sel kanker (PSA level) akan kembali naik. Meskipun jumlah kemoterapi cenderung sedikit, namun waktu sembuh pasien akan bertambah panjang.

\section{Model 2 (selang kemoterapi terlalu cepat):}




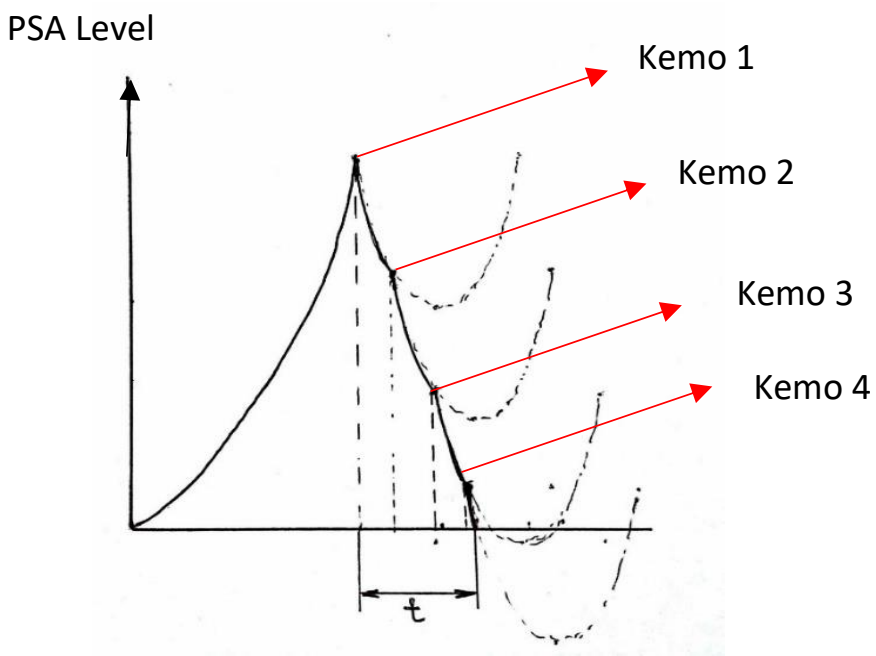

Gambar 6. Analisis Model 2

Model ini memperlihatkan bahwa selang antar kemoterapi yang dilakukan terlampau singkat, sehingga efek kemoterapi sebelumnya belum optimal habis. Meskipun waktu sembuh pasien lebih cepat, namun jumlah kemoterapi yang dibutuhkan lebih banyak. Hal ini menimbulkan resiko kematian yang lebih besar dikarenakan efek negatif yang disebabkan kemoterapi yang terlalu banyak.

\section{Model 3 (selang kemoterapi paling efektif):}

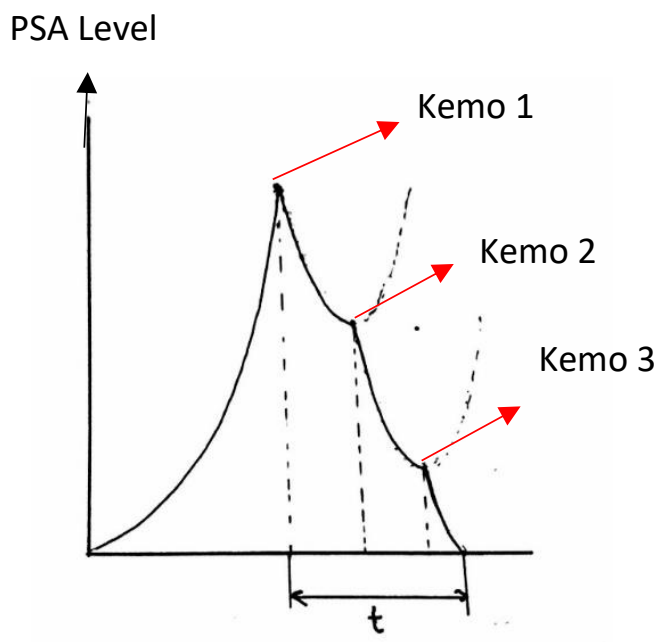

Gambar 7. Analisis Model 3

Model ini adalah model yang paling efektif. Gambar di atas menjelaskan bahwa tingkat keparahan pasien penyakit kanker akan berangsur-angsur turun. Dapat dilihat tingkat PSA pasien yang semakin berkurang terhadap waktu akibat adanya efek kemoterapi yang diberikan. Dan dapat dilihat bahwa pengobatan kemoterapi memiliki titik-titik stasioner (ditentukan oleh periode kemoterapi subbab sebelumnya) tertentu yang menunjukkan harus dilakukannya upgrade pengobatan secara berkala untuk memperbarui efek kemoterapi sehingga tingkat PSA turun sampai titik $4 \mathrm{ng} / \mathrm{ml}$.

Dengan pendekatan matematis dari data tumor marker tiap pasien, dapat diperkirakan kapan kanker muncul, karakterisitik pertumbuhan kanker tiap pasien, dan lama waktu penyembuhan. Data yang penulis bangun diharapkan dapat digunakan oleh pihak medis untuk menyusun strategi pengobatan agar efektif dan efisien, misalnya untuk penjadwalan pengobatan. Diharapkan dengan 
model yang telah dibuat dapat dikembangkan menjadi sebuah instrumentasi medik yang dapat dengan praktis digunakan oleh tenaga medik. Dan selain itu dapat dikembangkan tidak hanya untuk kanker prostat saja tetapi untuk kanker lainnya dengan indikator (tumor marker).

\section{Hasil dan Pengolahan Data Pasien Kanker Prostat}

Dalam penelitian ini penulis telah merumuskan variable-variabel yang digunakan sebagai berikut:

Tabel 1. Variabel yang digunakan dalam Pemodelan

\begin{tabular}{|c|c|c|}
\hline PSA(t) & Tingkat PSA terhadap waktu & $\mathbf{n g} / \mathbf{m l}$ \\
\hline PSA 1 & PSA saat Check Up 1 (belum pengobatan) & $\mathrm{ng} / \mathrm{ml}$ \\
\hline PSA 2 & PSA saat Check Up 2 (belum pengobatan) & $\mathrm{ng} / \mathrm{ml}$ \\
\hline PSA 3 & PSA saat Check Up 3 (sudah pengobatan) & $\mathrm{ng} / \mathrm{ml}$ \\
\hline PSA 4 & PSA saat Check Up 4 (sudah pengobatan) & $\mathrm{ng} / \mathrm{ml}$ \\
\hline $\mathbf{g}$ & Koefisien kenaikan tingkat PSA & hari $^{-1}$ \\
\hline d1 & $\begin{array}{l}\text { Koefisien penurunan tingkat PSA saat pengukuran Check Up } \\
3\end{array}$ & hari $^{-1}$ \\
\hline d2 & $\begin{array}{l}\text { Koefisien penurunan tingkat PSA saat pengukuran Check Up } \\
4\end{array}$ & hari $^{-1}$ \\
\hline$t_{0}$ & Selang waktu sebelum terkena kanker sampai Check Up 1 & hari \\
\hline $\mathbf{t}_{\mathbf{1}}$ & Selang waktu Check Up 1 dan Check Up 2 & hari \\
\hline $\mathbf{t}_{2}$ & Selang waktu Check Up 2 dan Check Up 3 & hari \\
\hline t3 & Selang waktu Check Up 2 dan Check Up 4 & hari \\
\hline$t_{\text {kemoterapi }}$ & Periode efektifitas kemoterapi & hari \\
\hline
\end{tabular}

Berikut adalah data pasien yang akan diolah:

Tabel 2. Data PSA Pasien

\begin{tabular}{cccccc}
\hline Pasien & $\begin{array}{c}\text { Umur } \\
\text { (tahun) }\end{array}$ & $\begin{array}{c}\text { Check up 1 } \\
\text { (PSA 1) }\end{array}$ & $\begin{array}{c}\text { Check Up 2 } \\
\text { (PSA 2) }\end{array}$ & $\begin{array}{c}\text { Check Up 3 } \\
\text { (PSA 3) }\end{array}$ & $\begin{array}{c}\text { Check Up 4 } \\
\text { (PSA 4) }\end{array}$ \\
$\mathbf{1}$ & 43 & 117.8 & 137.67 & 129.075 & 124.5 \\
$\mathbf{2}$ & 30 & 21.9 & 23.32 & 16.97 & 14.056 \\
$\mathbf{3}$ & 68 & 69.4 & 88.749 & 81.84 & 78.55 \\
\hline
\end{tabular}

Berdasarkan studi pustaka yang telah dilakukan, dari data PSA pasien diatas dapat dihasilkan suatu jadwal pengobatan yang sesuai dan tepat. Berikut adalah jadwal kemoterapi tiap pasien:

Tabel 3. Jadwal Pengobatan Kemoterapi Pasien 1

\begin{tabular}{ccccccc}
\hline & \multicolumn{2}{c}{ Pasien 1 } & & $\mathbf{4}$ & 67.24 & 97.125 \\
\hline Kemot & PSA(0) & Periode Kemoterapi & $\mathbf{5}$ & 52.953 & 97.125 \\
erapi & $(\mathrm{ng} / \mathrm{ml})$ & (hari) & 97.125 & $\mathbf{6}$ & 41.702 & 97.125 \\
\hline $\mathbf{1}$ & 137.67 & 97.125 & $\mathbf{7}$ & 32.841 & 97.125 \\
\hline $\mathbf{2}$ & 108.418 & 97.125 & $\mathbf{8}$ & 25.863 & 97.125 \\
\hline $\mathbf{3}$ & 85.384 & $\mathbf{9}$ & 20.268 & 97.125 \\
\hline
\end{tabular}




\begin{tabular}{ccc}
\hline $\mathbf{1 0}$ & 16.04 & 97.125 \\
\hline $\mathbf{1 1}$ & 12.632 & 97.125 \\
\hline $\mathbf{1 2}$ & 9.948 & 97.125 \\
\hline $\mathbf{1 3}$ & 7.834 & 97.125 \\
\hline $\mathbf{1 4}$ & 6.17 & 97.125 \\
\hline $\mathbf{1 5}$ & 4.86 & 55 \\
\hline
\end{tabular}

\begin{tabular}{cc}
\hline Waktu & $\mathbf{1 4 1 4 . 7 5}$ \\
Penyembuhan \\
(waktu yang \\
diperlukan untuk \\
mencapai PSA=4 \\
$\mathrm{ng} / \mathrm{ml}$ )
\end{tabular}

Tabel 4. Jadwal Pengobatan Kemoterapi Pasien 2

\section{Pasien 2}

\begin{tabular}{ccc}
\hline Kemoterapi & PSA(0) $(\mathrm{ng} / \mathrm{ml})$ & $\begin{array}{c}\text { Periode } \\
\text { Kemoterapi (hari) }\end{array}$ \\
\hline $\mathbf{1}$ & 23.32 & 164.442 \\
\hline $\mathbf{2}$ & 5.947 & 17 \\
\hline Waktu Penyembuhan & $\mathbf{1 8 1 . 4 4 2}$ \\
(waktu yang diperlukan & \\
untuk mencapai PSA=4 \\
ng/ml)
\end{tabular}

Tabel 5. Jadwal Pengobatan Kemoterapi Pasien 3

\begin{tabular}{|c|c|c|}
\hline \multicolumn{3}{|c|}{ Pasien 3 } \\
\hline Kemoterapi & $\begin{array}{c}\text { PSA(0) } \\
\text { (ng/ml) }\end{array}$ & $\begin{array}{c}\text { Periode } \\
\text { Kemoterapi } \\
\text { (hari) }\end{array}$ \\
\hline $\mathbf{1}$ & 88.749 & 90.534 \\
\hline $\mathbf{2}$ & 67.357 & 90.534 \\
\hline $\mathbf{3}$ & 51.122 & 90.534 \\
\hline $\mathbf{4}$ & 38.7999 & 90.534 \\
\hline $\mathbf{5}$ & 29.448 & 90.534 \\
\hline $\mathbf{6}$ & 22.3499 & 90.534 \\
\hline
\end{tabular}

\begin{tabular}{|c|c|c|}
\hline 7 & 16.9628 & 90.534 \\
\hline 8 & 12.8742 & 90.534 \\
\hline 9 & 9.771 & 90.534 \\
\hline 10 & 7.4158 & 90.534 \\
\hline 11 & 5.62833 & 90.534 \\
\hline 12 & 4.2717 & 11 \\
\hline \multicolumn{2}{|c|}{$\begin{array}{c}\text { Waktu Penyembuhan } \\
\text { (waktu yang diperlukan } \\
\text { untuk mencapai PSA=4 } \\
\text { ng/ml) }\end{array}$} & 1006.874 \\
\hline
\end{tabular}

\section{KESIMPULAN}

Kuantitas sel kanker yang telah tumbuh dapat diidentifikasi dengan kadar tumor marker dalam darah. Salah satu jenis tumor marker adalah PSA (prostat specific antigen) yang merepresentasikan jumlah kanker prostat yang telah tumbuh. Tingkat PSA dalam jangka waktu tertentu sebelum dan sesudah pasien diobati dapat digunkanan untuk mendapatkan karakteristik pertembuhan kanker. Persamaan pertumbuhan PSA dapat diturunkan dari tiga titik data: (1) tingkat PSA awal, saat check up pertama (2) tingkat PSA saat pengobatan dimulai, saat check up kedua dan (3) tingkat PSA pasca pengobatan, saat check up ketiga dan keempat. Umur kanker (dihitung dari kanker pertama kali muncul sampai check up pertama) dapat dhitung dengan persamaan $\boldsymbol{t}_{\mathbf{0}}=\frac{1}{\boldsymbol{g}} \boldsymbol{l n}\left|\frac{\boldsymbol{P S \boldsymbol { A }} \mathbf{1}}{\mathbf{4}}\right|$. Selain itu bisa ditentukan periode kemoterapi untuk membuat model efektifitas kemoterapi pengobatan dengan persamaan 


$$
t_{\text {kemoterapi }}=t 2 \cdot \ln \left|\frac{g}{\sqrt[t z-t s]{\sqrt{\frac{d 2^{t 2}}{d 1^{t 3}}}}}\right| \div \ln \left|\frac{d 1}{\mid t 2-t s} \sqrt{\frac{d 2^{22}}{d 1^{13}}}\right|
$$

Lama fase pertumbuhan kanker masing-masing pasien berbeda-beda dikarenakan beberapa faktor dalam tubuh manusia sendiri. Misalnya sel imun yang berfungsi sebagai kekebalan tubuh. Di tubuh pasien yang memiliki sistem imun yang lebih kuat, maka pertumbuhan kanker akan cenderung lebih lambat (berhubungan terbalik). Lama fase penyembuhan (kemoterapi) masing-masing pasien juga berbeda-beda dikarenakan sensitifitas tubuh manusia terhadap obat berbeda. Sehingga ada pasien yang memerlukan waktu yang lebih sedikit dan juga ada pasien yang membutuhkan waktu lebih lama dalam fase penyembuhan (berhubungan dengan periode kemoterapi). Analisis mengenai perhitungan periode kemoterapi pada pasien dapat dihitung secara presisi. Dengan itu dokter dapat mengetahui waktu melakukan kemoterapi selanjutnya pada pasien sekaligus memperhatikan efektititas pengobatan kepada pasien. Dengan hal itu, dapat ditekan faktor lama kesembuhan dan biaya pengobatan dari pasien itu sendiri. Disisi lain, ahli medis juga dapat meningkatkan efektifitas kinerja mereka.

\section{DAFTAR PUSTAKA}

Aetna. 2016. Tumor Markers. Aetna Inc. http://www.aetna.com/cpb/medical/data/300_399/0352.htm/ Dikunjungi 12 Juli 2019.

Boyce, William E., DiPrima, Richard C. 2001. Elementary Differential Equations and Boundary Value Problems Seventh Edition. New York: John Wiley \& Sons, Inc.

Castillo, Carlos \& Chavez. 2001. Mathematical Models in Population Biology and Epidemiology. New York: Springer.

Girodano, Frank R., Fox, William P., Horton, Steven B. 2014. A First Course in Mathematical Modeling Fifth Edition. Boston: Brooks/Cole.

Mendelsohn, John., Gray, Joe W., Howley Peter M., Israel, Mark A., Tompson, Cralg B. 2015. The Molecular Basis of Cancer. Philadelphia : Saunders, an imprint of Elsevier Inc.

Stein, Wilfred D, Figg, William D. 2008. Tumor Growth Rates Derived from Data for Patients in a Clinical Trial Correlate Strongly with Patient Survival: A Novel Strategy for Evaluation of Clinical Trial Data. The National Center for Biotechnology Information.

http://www.ncbi.nlm.nih.gov/pmc/articles/PMC3313464/ Dikunjungi 2 Juli 2019.

http://www.depkes.go.id/article/view/19020100003/hari-kanker-sedunia-2019.html Dikunjungi 14 September 2019 